\title{
NPY and sbGnRH gene expression in juvenile and adult male Brazilian flounder Paralichthys orbignyanus
}

\author{
Expressão gênica do NPY e do sbGnRH em machos juvenis e adultos de linguado \\ Paralichthys orbignyanus
}

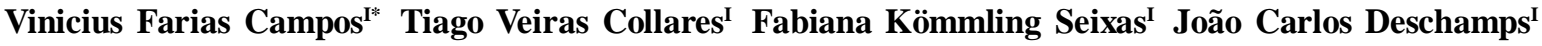 Luis Fernando Fernandes Marins ${ }^{\mathrm{II}}$ Marcelo Hideo Okamoto ${ }^{\mathrm{II}}$ Luís André Nassr Sampaio ${ }^{\mathrm{II}}$ Ricardo Berteaux Robaldo ${ }^{\mathrm{III}}$}

\section{- NOTE -}

\begin{abstract}
The objective of this study was to evaluate neuropeptide $Y(N P Y)$ and sea bream gonadotropin-release hormone (sbGnRH) gene expression in juvenile and adult males of Brazilian flounder. Hypothalamuses from fish were sampled for total RNA extraction. After cDNA synthesis, real-time PCR was used to measure gene expression. NPY showed approximately 2-fold increases in their mRNA levels while sbGnRH showed 3-fold increases in adult fish. These results suggest that these peptides could be involved on hypothalamic regulation of Brazilian flounder sexual maturation.
\end{abstract}

Key words: sexual maturation, fish, Pleuronectiformes, mRNA.

\section{RESUMO}

O objetivo deste estudo foi avaliar a expressão gênica do neuropeptídeo $Y(N P Y)$ e da variante sea bream do hormônio liberador de gonadotrofinas ( $s b G n R H)$ em linguados machos juvenis e adultos. $O$ hipotálamo foi isolado para a extração de RNA total. Após a síntese de cDNA, a PCR em tempo real foi usada para avaliar a expressão gênica. Foi observado um aumento de aproximadamente duas vezes nos níveis de NPY e de aproximadamente três vezes nos níveis de sbGnRH nos peixes adultos. Esses resultados demonstram que estes peptídeos podem estar envolvidos na regulação, via hipotálamo, da maturação sexual no linguado.

Palavras-chave: maturação sexual, peixes, Pleuronectiformes, RNAm.
Body weight is extremely important for initiating and maintaining reproductive function. When weight falls below a physiological threshold, it can result in delayed puberty in juveniles. In opposite, body weight gain anticipates the puberty. The neuropeptide Y (NPY) is the most important stimulants of food intake and body weight gain in vertebrates, including mammals and fish (VOLKOFFet al., 2009). In mammals, NPY has been shown to both inhibit GnRH-1 release and neuronal activity as well as stimulate GnRH-1 secretion, depending on the metabolic and reproductive status of the animals used (LEBRETHON et al., 2007). Also, a direct effect of NPY on GnRH-1 neurons is possible because NPY fibers originating from the arcuate nucleus (ARC) have been shown to appose GnRH-1 neurons in mammals (WARD et al., 2009).

The sea bream GnRH (sbGnRH) or GnRH-1 has been appointed as the responsible by gonadal maturation in the Pleuronectiformes (PHAM et al., 2007). In addition, the NPY has been associated with food intake in several fish species as well as for Brazilian flounder (CAMPOS et al., 2010). Moreover, NPY was found to augment $\mathrm{LH}$ secretion via stimulation of $\mathrm{GnRH}$ release in rainbow trout (BRETON et al., 1991) and goldfish (PENG et al., 1990). As described above for mammals, there are evident relationships between NPY

\footnotetext{
INúcleo de Biotecnologia, Centro de Desenvolvimento Tecnológico, Universidade Federal de Pelotas (UFPel), CP 354, 96010900, Pelotas, RS, Brasil. E-mail: fariascampos@gmail.com. *Autor para correspondência.

"Universidade Federal do Rio Grande (FURG), Rio Grande, RS, Brasil.

${ }^{\text {III }}$ Departamento de fisiologia e Farmacologia, Instituto de Biologia, UFPel, Pelotas, RS, Brasil.
} 
and $\mathrm{GnRH}$, however, for fish species these interactions were rarely studied. The Brazilian flounder inhabits the estuarine and coastal waters from Rio de Janeiro (Brazil) to Mar del Plata (Argentina) breeds during the spring months reaching first gonadal maturation with a minimum size of $26 \mathrm{~cm}$ for males and $38 \mathrm{~cm}$ for females (SILVEIRA et al., 1995). Also, this species has demonstrated great potential for aquaculture. Considering the knowledge for mammals on relationship between NPY and GnRH this study demonstrate the in vivo hypothalamic expression of these two genes in the juvenile and adult Brazilian flounder.

Fish were obtained by artificial spawning at the Aquaculture Station at FURG (Brazil). To evaluate the effects of sexual maturation on sbGnRH and NPY gene expression, five juvenile male fish $(71.4 \pm 13.0 \mathrm{~g}$; $17.8 \pm 1.0 \mathrm{~cm})$ and five adult males $(463.2 \pm 42.2 \mathrm{~g}$; $34.1 \pm 0.6 \mathrm{~cm})$ were used. Fish were allocated in tanks with 500L for juveniles and 2000L for adults over 3 weeks to allow acclimation in seawater. They were fed with commercial pellets (Supra Salmonídeos ${ }^{\mathrm{TM}} / \mathrm{Alisul} /$ Brazil) containing $46 \%$ crude protein and $6 \%$ lipid once a day at the same time under natural temperature $\left(21.5^{\circ} \pm 0.8^{\circ} \mathrm{C}\right)$, photoperiod (12L: $\left.12 \mathrm{D}\right)$, salinity $\left(32.6 \pm 1.1 \%\right.$ ) , dissolved oxygen $\left(6.8 \pm 0.3 \mathrm{mg} \mathrm{O}_{2} \mathrm{~L}^{-1}\right)$. Before sampling, sperm was collected using $1 \mathrm{~mL}$ syringes by manual stripping at the abdominal region. Fish were randomly sampled, anaesthetized with benzocain $\left(50 \mathrm{mg} \mathrm{l}^{-1}\right)$ and euthanized by severing the spinal cord. The gonads were dissected, and their weights were measured to calculate the gonadosomatic index $(\mathrm{GSI}=$ [gonadal weight/body weight $] \times 100)$. The brain without cerebellum and medulla oblongata was quickly dissected out and frozen in liquid nitrogen until use (AMANO et al., 2004). Total RNA extraction and cDNA synthesis were performed as previously described (CAMPOS et al., 2010). Real-Time PCR reactions were run on a Stratagene ${ }^{\circledR} \mathrm{Mx} 3005 \mathrm{P}^{\mathrm{TM}}$ RealTime PCR System (Agilent Technologies ${ }^{\oplus}$, Santa Clara, CA, USA) using Platinum ${ }^{\circledR}$ SYBR $^{\circledR}$ Green qPCR SuperMix UDG (Invitrogen ${ }^{\mathrm{TM}}$, Carlsbad, USA). Primers for NPY (GenBank \# FJ705358 - forward 5' CACGTCATTTTCCTCCTGCAT 3', reverse 5', GCATAGCGGCTCGTAGAGGTA 3'), sbGnRH (GenBank \# GQ220297 - forward 5, ATGCACAGAGAAATGGCTGTG 3', reverse 5' TCATTTCTTATAAGTTCTGCGTCC 3') and the endogenous reference B-actin (GenBank \# EU542580 forward 5' GACCCAGATCATGTTTGAGACCTT 3', reverse 5' AGGGACAGCACAGCTTGGAT 3') were designed with the Primer3 software (http:// frodo.wi.mit.edu/primer3) (CAMPOS et al., 2011). Initial validation experiments were conducted to ensure that all primer pairs had equivalent PCR efficiencies. Amplification was carried out at cycling conditions of $95^{\circ} \mathrm{C}$ for $2 \mathrm{~min}$, followed by 40 cycles at $95^{\circ} \mathrm{C}$ for $15 \mathrm{sec}$, $60^{\circ} \mathrm{C}$ for $60 \mathrm{sec}$ followed by conditions to calculate the melting curve. All PCR runs for each cDNA sample, which were performed in triplicate. The real time PCR data were analyzed using Relative Expression Software Tool - REST-2009 ${ }^{\circ}$ (PFAFFL et al., 2002). Student's $t$ test was used to compare gene expression and GSI data. Statistical differences were considered at $\mathrm{P}<0.05$. All data are expressed as means \pm SEM.

GSI values are shown in figure 1a in which it can be seen that the GSI was significant increased from the juvenile to adult fish $(\mathrm{P}<0.05)$. In addition, it was possible to collect sperm by manual stripping from all adult fish while no sperm was found in juvenile fish. Primer efficiencies for NPY, sbGnRH and $\beta$-actin primers sets had 104, 90 and 107\%, respectively, showing their feasibility for gene expression analysis. Figure $1 \mathrm{~b}$ and $1 \mathrm{c}$ shows the evaluation of hypothalamic NPY and sbGnRH gene expression for male Brazilian flounder demonstrating that between juvenile and adult male fish, the mRNA levels for NPY increases approximately 2 -fold $(\mathrm{P}<0.05)$ and sbGnRH increases 3 -fold approximately $(\mathrm{P}<0.05)$. A first observation on this data reveals that gonadal maturation may affect the expression of both genes, however, more studies must be conducted to elucidate the role of these two genes in the gonadal maturation. A previous report for rats (HWANG et al., 2001), demonstrates an age-related increase in the number and size of NPY-immunoreactive neurons in the anterior olfactory nucleus and correlates the same with olfaction and sexual maturation, as well as NPY gene expression is augmented in the hypothalamus of older women (ESCOBAR et al., 2004). Studies using catfish males brain demonstrates that testosterone injection significantly augmented NPY immunoreactivity in nucleus entopeduncularis (NE) of juveniles, however these levels were more limited in the testosterone-treated and control groups than in adults (MAZUMDAR et al., 2007). As demonstrated for rats (KALRA et al., 1997), this data suggest that NPY-containing neurons of NE may convey the positive feedback influence of the sex steroids to the GnRH secretion. Here, it is also demonstrated an increase in the sbGnRH mRNA levels in the hypothalamus of Brazilian flounder.

Interactions between appetite-regulating hormones and reproductive hormones, in particular GnRH, have been demonstrated in fish. The hypothalamus in fishes exerts its regulation on the release of gonadotropins via several neurohormones 
a)

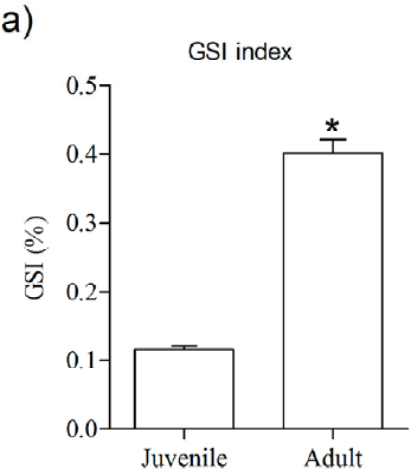

b)

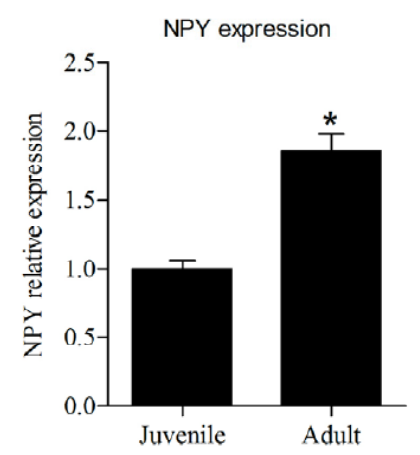

c)

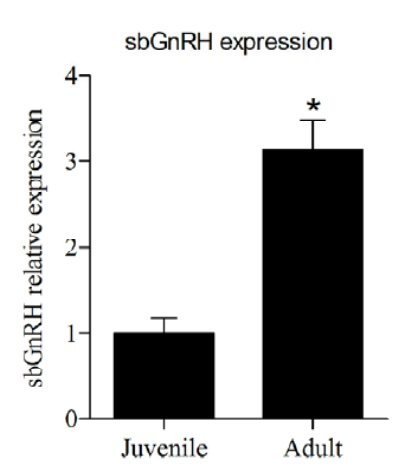

Figure 1 - GSI index for males at the moment of fish sampling and evaluation of Paralichthys orbignyanus hypothalamic NPY and sbGnRH gene expression in juvenile and adult male fish. Panel a) shows the GSI index for juvenile and ADULT fish. b) represents NPY relative expression and panel c) represents sbGnRH relative expression. Dare expressed as means \pm SEM $(N=5)$.

such as GnRH and NPY. Thus, gonadal steroids and peptides exert their effects on the gonadotropins either directly or via e hypothalamus (LEVAVI-SIVAN et al., 2010). The sbGnRH has been strongly associated with gonadal maturation in the pleuronectiform fishes (PHAM et al., 2007). However, little information regarding the stimulation effects for $\mathrm{sbGnRH}$ secretion are currently available. These data provide evidence that the close relationship between NPY and GnRH neurons demonstrated for mammals (KLENKE et al., 2010) may also exist in fish. In goldfish, NE stimulates LH release only during gonadal regression (PETER et al., 1986), whereas NPY in goldfish (BRETON et al., 1991) is more prominent in mature than in sexually regressed fish. In summary, NPY and sbGnRH mRNA levels are increased in adult Brazilian flounder and these two genes may play a key role in sexual maturation.

\section{ACKNOWLEDGEMENTS}

To MCT/CNPq-Edital Universal (\# 47438/20067) which supported this study.

\section{ETHICS AND BIOSAFETY COMMITTEE}

The present study was approved by Ethics Committee on Animal Experimentation from UFPel (\#1306/ 2011-01).

\section{REFERENCES}

AMANO, M. et al. Changes in brain GnRH mRNA and pituitary GnRH peptide during testicular maturation in barfin flounder. Comparative Biochemistry and Physiology B, v.138, p.435-443, 2004. Available from: <linkinghub.elsevier.com/ retrieve/pii/S1096495904001484>. Accessed: Feb. 26, 2011. doi:10.1016/j.cbpc.2004.05.005.
BRETON, B. et al. Neuropeptide $\mathrm{Y}$ stimulates in vivo gonadotropin secretion in teleost fish. General and Comparative Endocrinology, v.84, p.277-283, 1991. Available from: <linkinghub.elsevier.com/retrieve/pii/ 001664809190050G>. Accessed: Feb. 26, 2011. doi:10.1016/ 0016-6480(91)90050-G.

CAMPOS, V.F. et al. Clonagem e avaliação da expressão gênica do sbGnRH em machos juvenis e adultos de linguado, Paralichthys orbignyanus. Arquivo Brasileiro de Medicina Veterinária e Zootecnia, v.63, p.239-246, 2011. Available from: <http:/ /www.scielo.br/pdf/abmvz/v63n1/v63n1a34.pdf>. Accessed: Jul. 31, 2011. doi: 10.1590/S0102-09352011000100034.

CAMPOS, V.F. et al. Identification, tissue distribution and evaluation of brain neuropeptide $\mathrm{Y}$ gene expression in the Brazilian flounder Paralichthys orbignyanus. Journal of Biosciences, v.35, p.405-413, 2010. Available from: <www.ias.ac.in/jbiosci/sep2010/405.pdf〉. Accessed: Feb. 26, 2011. doi: I 10.1007/s12038-010-0046-y.

ESCOBAR, C.M. et al. Neuropeptide Y gene expression is increased in the hypothalamus of older women. Journal of Clinical Endocrinology \& Metabolism, v.89, p.2338-2343, 2004. Available from: <http://jcem.endojournals.org/cgi/ content/abstract/89/5/2338>. Accessed: Feb. 26, 2011. doi: 10.1210/jc.2003-031899.

HWANG, I.K. et al. Age-related change of neuropeptide Yimmunoreactive neurons in the rat anterior olfactory nucleus. Journal of Neurocytology, v.30, p.967-972, 2001. Available from: 〈www.springerlink.com/index/vt066745657286hl.pdf〉. Accessed: Feb. 27, 2011. doi: 10.1023/A:1021880405862.

KALRA, S.P. et al. The interactive language of the hypothalamus for the gonadotropin releasing hormone $(\mathrm{GnRH})$ system. Journal of Neuroendocrinology, v.9, p.569-576, 1997. Available from: <http://onlinelibrary.wiley.com/doi/ 10.1046/j.1365-2826.1997.00619.x/pdf >. Accessed: Feb. 27, 2011. doi: 10.1046/j.1365-2826.1997.00619.x.

KLENKE, U. et al. Neuropeptide Y directly inhibits neuronal activity in a subpopulation of gonadotropin-releasing hormone- 
1 neurons via Y1 receptors. Endocrinology, v.151, p.27362746, 2010. Available from: <http://endo.endojournals.org/ cgi/content/abstract/151/6/2736>. Accessed: Feb. 27, 2011. doi: 10.1210/en.2009-1198.

LEBRETHON, M.C. et al. Effects of in vivo and in vitro administration of ghrelin, leptin and neuropeptide mediators on pulsatile gonadotrophin-releasing hormone secretion from male rat hypothalamus before and after puberty. Journal of Neuroendocrinology, v.19, p.181-188, 2007. Available from: <http://onlinelibrary.wiley.com/doi/10.1111/j.13652826.2006.01518.x/pdf>. Accessed: Feb. 27, 2011. doi: 10.1111/j.1365-2826.2006.01518.x.

LEVAVI-SIVAN, B. et al. Perspectives on fish gonadotropins and their receptors. General and Comparative Endocrinology, v.165, p.412-437, 2010. Available from: <http://www.sciencedirect.com/science/article/pii/ S0016648009003220>. Accessed: Feb. 27, 2011. doi:10.1016/ j.ygcen.2009.07.019.

MAZUMDAR, M. et al. Reproduction phase-related variations in neuropeptide $\mathrm{Y}$ immunoreactivity in the olfactory system, forebrain, and pituitary of the female catfish, Clarias batrachus (Linn.). Journal of Comparative Neurology, v.504, p.450469, 2007. Available from: <http://onlinelibrary.wiley.com/ doi/10.1002/cne.21462/pdf>. Accessed: Feb. 27, 2011. doi: $10.1002 / \mathrm{cne} .21462$.

PENG, C. et al. Neuropeptide Y stimulates growth hormone and gonadotropin release from the goldfish pituitary in vitro. Neuroendocrinology, v.52, p.28-34, 1990. Available from: <http://endo.endojournals.org/cgi/content/abstract/132/4/ 1820>. Accessed: Feb. 27, 2011. doi: 10.1210/en.132.4.1820.
PETER, R.E. et al. Interactions of catecholamines and GnRH in regulation of gonadotropin secretion in teleost fish. Recent Progress in Hormone Research, v.42, p.513-548, 1986.

PFAFFL, M.W. et al. Relative expression software tool (REST) for group-wise comparison and statistical analysis of relative expression results in real-time PCR. Nucleic Acids Research, v.30, p.e36, 2002. Available from: <http:// nar.oxfordjournals.org/content/30/9/e36.full.pdf + html $>$. Accessed: Feb. 27, 2011. doi: 10.1093/nar/30.9.e36.

PHAM, K.X. et al. Immunohistochemical localization of three GnRH systems in brain and pituitary of Japanese flounder. Fisheries Science, v.73, p.1113-1122, 2007. Available from: <www.springerlink.com/index/X57887VNV7410P51.pdf >. Accessed: Feb. 27, 2011. doi: 10.1111/j.14442906.2007.01443.x.

SILVEIRA, M.P.M. et al. Testicular and ovaric structure of the flounder Paralichthys orbignyanus. Atlântica, v.17, p.135152, 1995. Available from: <http://www.lei.furg.br/atlantica/ vol17/r111795.htm>. Accessed: Feb. 27, 2011

VOLKOFF, H. et al. Aspects of the hormonal regulation of appetite in fish with emphasis on goldfish, Atlantic cod and winter flounder: notes on actions and responses to nutritional, environmental and reproductive changes. Comparative Biochemistry and Physiology A, v.153, p.8-12, 2009 Available from: <linkinghub.elsevier.com/retrieve/pii/ S1095643308012336>. Accessed: Feb. 27, 2011. doi: 10.1016/ j.cbpa.2008.12.001.

WARD, D.R. et al. Innervation of gonadotropin-releasing hormone neurons by peptidergic neurons conveying circadian or energy balance information in the mouse. PLoS One, v.4, p.e5322, 2009. Available from: <http://www.plosone.org/article/ info:doi/10.1371/journal.pone.0005322>. Accessed: Feb. 27, 2011. doi: 10.1371/journal.pone.0005322. 